carrying out the deformation by hammering, two small specimens, each weighing about one gram, were used. The temperature was raised to $900^{\circ} \mathrm{C}$. and then lowered in about ten minutes to $695^{\circ} \mathrm{C}$. After fifteen minutes the manganese steel rod was carefully placed on one of them, and a smart blow given with a hammer. To neutralise the effect of any slight difference in temperature between the end of the rod and the pieces, the rod was also placed on the other, but no blow was given. The positions of the two pieces were then interchanged. After an interval of ten minutes, the temperature still being $695^{\circ} \mathrm{C}$., the above procedure was repeated in varying order about six times, and after a further five minutes the specimens were quenched in water. The deformations produced were comparatively small, not exceeding $\frac{1}{40}$ of an inch. Repeated experiments all agreed in showing that the lag at $\mathrm{Ar}$ I was diminished by this slight deformation. The author shows two photomicrographs. In one of these (the hammered specimen) fully half the austenite areas have been converted into pearlite. In the other (an unhammered piece) only one such area has undergone a change.

The same apparatus was used in the deformation by bending experiments. A V-shaped notch, $\frac{1}{8}$ of an inch deep, was cut in the top of the anvil, and the end of the manganese steel rod was shaped like a chisel. The metal used was a mild steel strip $\frac{1}{2}$ in. $\times \frac{3}{16}$ in. $\times \frac{1}{16}$. This was placed across the notch, heated to $900^{\circ} \mathrm{C}$. and cooled to $695^{\circ} \mathrm{C}$. After fifteen minutes the rod was placed upon it so that the end was in line with the notch, and two or three light blows were given with the hammer. In this way the strip was bent to an angle of about $60^{\circ}$. After a further five minutes at $695^{\circ} \mathrm{C}$. the strip was taken out and quenched. This experiment was made repeatedly, always with the same result. At the bend, as shown in the author's photomicrograph, pearlite was always present, but in the limbs where the metal had not been distorted, the structure consisted almost entirely of ferrite and martensite. A similar but less pronounced effect was produced when strips were bent while being maintained at a temperature of $700^{\circ} \mathrm{C}$.

The author states in conclusion that although lag was reduced, it was not completely eliminated by the methods of deformation used, since, in a previous investigation with the same steel, globular pearlite was found to grow between $705^{\circ}$ and $708^{\circ} \mathrm{C}$. when carbide nuclei were present in the austenite. Both hammering and bending tests, however, agree in showing that the lag at $\mathrm{Ar}$ I can be appreciably diminished through deformation.

\title{
Medical Education.
}

THE professional course has grown so full in the training of a medical student that it has become increasingly difficult to cover the ground and secure qualification in a reasonable time. Some years ago this fact raised in an acute form the position of the preliminary examinations in the pure sciences. If these examinations were abolished, or placed outside the professional course, obviously a gain in time would result for abler students. The best account of the matter is to be found in the appendix to the fifth report of the Royal Commission on University Education in London-especially under the evidence of Sir $\mathrm{H}$. Morris, Mr. Flexner, and others. The practice in other countries in regard to the preliminary sciences is also clearly described.

The new regulations of the General Medical Council in regard to student registration presumably indicate the conclusions of that body on the problem. The preliminary sciences are retained, but two of them are placed outside the professional course; at the same time the age of student registration is raised to seventeen years. The examinations in chemistry and physics must be passed before registration but after the examination in general education. Biology may not be taken until after registration.

The examinations in these preliminary sciences must be conducted or recognised by one of the existing licensing bodies. It remains to be seen what provision the licensing bodies will make for these pre-registration examinations. The Conjoint Board has not yet issued its regulations. Student registration is, of course, at present not legally obligatory, but the older licensing bodies, such as the Universities of Oxford and Cambridge, usually conform so far as possible to the requirements of the General Medical Council. It is at present unlikely that either Oxford or Cambridge will alter its current practice. Each will continue to conduct its present preliminary examinations and postpone student registration until after they have been passed.

These examinations can all of them now be taken under certain conditions before residence is begun. This comparatively recent concession on the part of these universities leaves their candidates practically unaffected by the new General Medical Council regulations. Boys going to these universities will postpone registration until after.passing the preliminary examinations instead of, as at present, registering when they have passed the general education examination. It is not unlikely, however, that both Oxford and Cambridge may extend recognition to biology in their own Higher Certificate examinations - they will inevitably do so some day. This would prevent a hardship which may occur at present to a boy who can only proceed to the university if he wins a scholarship. The university scholarships are open up to nineteen years of age. If a boy waits for these and is unsuccessful, he would have obtained his qualification more quickly by leavirig school at seventeen years of age and proceeding straight to a hospital. If he is allowed a certificate for all the preliminary sciences on the Higher Certificate examination, such a boy would lose less time.

\section{The Chilian Earthquake.}

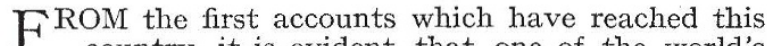
country, it is evident that one of the world's greatest earthquakes occurred shortly before midnight on November IO-II off the coast of Chile. As in all such earthquakes, the duration of the shock was considerable-nearly three minutes at Valparaiso and four minutes at Caldera-but it should be remembered that such estimates may include some of the immediately succeeding after-shocks. There can be no doubt, however, as to the great extent of the disturbed area. Along the coast, the shock was felt from Antofagasta to Valdivia, a distance of I Ioo miles. It was felt across the continent at Buenos Ayres, where it was strong enough to stop clocks. As this city is about 900 miles from Coquimbo (which appears to be near the epicentre), the disturbed area must contain more than $2 \frac{1}{2}$ million square miles. The shock is also said to have been felt at Hilo, in Hawaii, but, without further and much stronger evidence, the statement may be discredited. The district over 
which houses were damaged was also large, though perhaps not unusually large. The zone most affected was that between Coquimbo and Chanaral, the latter place being nearly Ioo miles north of Coquimbo, but houses were also slightly damaged at Valparaiso, which lies about 240 miles to the south.

In this earthquake, as in so many others on the western coast of America, it is difficult in the early accounts to separate the effects of the shock from those produced by the sea-waves and by the fires that followed the earthquake. The sea-waves were observed along the coast from at least Antofagasta on the north to Talcahuano (near Concepcion) on the south, a distance of nearly a thousand miles. They were large enough to wash away boats at Hilo in Hawaii. All the submarine cables along the coast appear to be broken, but the statement that soundings taken between Copiapo and Caldera gave a depth of 86 fathoms, instead of 2800 fathoms as marked on the chart, must of course be erroneous. The earthquake resembles its predecessors in its submarine origin some distance from the coast.

\section{University and Educational Intelligence.}

BIRMINGHAM.-The following appointments have been made by the Council: Mr. A. W. Nash, lecturer in oil mining; Dr. E. Ashley Cooper, lecturer in public health chemistry; and Mr. D. R. Nanji, assistant lecturer and demonstrator in the department of brewing and the biochemistry of fermentation.

CAmbridge.-Mr. G. C. Stèward has been elected to a fellowship at Gonville and Caius College, and Mr. G. Udny Yule, Mr. J. E. P. Wagstaff, and Mr W. M. H. Greaves to fellowships at St. John's College.

LoNDon.-The Senate invites applications for a new University Chair of Anatomy tenable at St. Bartholomew's Hospital Medical College, which has not hitherto had a professor of the subject attached to it. The present University professors of anatomy are as follows: Prof. E. Barclay-Smith, King's College ; Prof. J. E. S. Frazer, St. Mary's ; Prof. T. B. Johnston, Guy's; Prof. F. G. Parsons, St. Thomas's ; Prof. G. Elliot Smith, University College ; Prof. W. Wright, London ; and Prof. T. Yeates, Middlesex. The full title of the holder of the chair at St. Bartholomew's will be "Professor of Anatomy in the University of London." The appointment will date from September I, I923, and will be subject to the statutes and regulations of the University and to the regulations of St. Bartholomew's Hospital Medical College. The professor will be expected to devote his whole time to the duties of the chair, except that he may be permitted to hold examinerships in anatomy, and will be able to devote time to research. The salary of the chair will be roool. per annum. Arrangements for assistance and for departmental expenditure are made by the Medical College of St. Bartholomew's Hospital in consultation with the professor. Applications for the chair (I2 copies) must be received not later than first post on April 16, 1923, by the Academic Registrar, University of London, South Kensington, London, S.W.7, from whom further particulars may be obtained.

ST. ANDREws.-Mr. Rudyard Kipling has been elected Rector in succession to Sir James M. Barrie.

Sheffield,-Mr. R. Stoneley, assistant lecturer in mathematics, has been appointed curator of the University Observatory.

Prof. Alfred Tennyson Delury, head of the department of mathematics, University of Toronto, was in June last appointed Dean of the Faculty of
Arts of that Uniwersity. Sir Robert Falconer, president of the University, called a meeting of the Council of the Faculty of Arts and announced that, while the appointment of a Dean was by statute in his hands, he would like to receive nominations from the Council for an appointment to this important post. Nominations were accordingly made and balloting was carried on by mail.

The first meeting of the Court of Governors of the University College of the South-West of England, Exeter, was held on October 27. The new governing body takes over the former Royal Albert Memorial College, Exeter, with its hostels and other property, and also enters into possession of the site and mansion-house given by Mr. W. H. Reed for the purposes of the new college buildings. The new University College which, on the recommendation of the University Grants Committee, has been placed upon the Treasury list of Universities and University Colleges as from August I, I922, is regarded as the first step towards the establishment of a University in the South-West of England. H.R.H. the Prince of Wales and Duke of Cornwall is president of the college, and sent a message of greeting and good wishes on the occasion of the first meeting of the court. The court elected Sir Henry Lopes, Bart., as deputy-president of the college : and one of the vice-presidents is Sir Arthur Quiller-Couch. The deputy-president made a statement to the court as to the present position and prospects of the college, emphasising his view that the governing principle of college policy should be the attainment, as soon as possible, of a status which would free the college from a purely external degree system, and indicating the possibilities of co-operation to this end among the various higher educational institutions in the south-western countries. A very substantial increase in the number of full-time degree students in attendance at the college was reported.

ON the occasion of the transfer of the Imperial Department of Agriculture from Barbados to Trinidad, following upon its amalgamation with the West Indian Agricultural College, Sir Francis Watts, principal of the College and Commissioner of Agriculture, received a letter from the Acting Governor of Barbados in which the latter stated that the department's work " has been a landmark in the history of the West Indian Colonies." He continued, "I beg also to be allowed to express the cordial gratitude of the Government of Barbados for the valuable and ready assistance which the Imperial Department has rendered the local Government on numerous occasions may I also assure you of the warm good wishes of the Barbados Government for the success and prosperity of the Agricultural College in which the Department will now be merged, and of our confident hope that the establishment of the College will prove to be a great step forward in the development of scientific tropical agriculture not only in the West Indies but also in a wider field,"

The Royal Technical College, Glasgow, publishes for the session I922-23, in a calendar comprising 356 closely printed pages, a vast amount of information relating not only to the courses of instruction it offers, the conditions under which the diplomas and degrees for which it prepares are obtainable, and the scholarships tenable in it, but also to the appointments now held by its past students. The list of past students and their appointments, including nearly a thousand names, affords convincing evidence of the practical value of the instruction given, and should be of great interest alike to past, present, and prospective students.

No. 2768 , vOL. I IO] 